\title{
A KOLOZSVÁRI EGYETEMEN OKTATOTT „NEMZETI IRODALMAK" FOGALMAINAK VERSENGÉSE AZ 1870-ES ÉVEKBEN
}

\author{
Dr. Nagy Zabán Márta \\ posztdoktori kutató, Babeş-Bolyai Tudományegyetem, Kolozsvár, Románia
}

\section{SUMMARY}

In this paper, through the example of the Hungarian and Romanian language and literature department of the Hungarian Royal University of Kolozsvár I have attempted to analyze that the establishment of the university in Kolozsvár at a certain point of the history of professionalization was not organized according to the logic of evolution history, its tendency of forming cannot be described as a progress from a less professionalized state to an increasingly professionalized and specialized state, in fact, by inheriting several elements from the structures of the earlier phases of the history of professionalization it elaborated its administrative framework according to the local special circumstances and to the requirements and decisions set out by Budapest, and defined its premises of scientific ideology.

Kulcsszavak: irodalomoktatás, egyetemtörténet, hivatásosodás, magyar, román

\section{RÖVIDEN A TÉMÁRÓL}

A Kolozsvári Magyar Királyi Tudományegyetem 1872. november 10-i hivatalos megnyitása speciális hivatásosodástörténeti kontextusba ágyazódik. Az új intézmény képviselöinek első reprezentációi a hatalom struktúráiban látjảk a szaktudományt elgondolhatónak, és mindenképpen a nemzetreprezentáció keretei között. Az itt következő tanulmány alapkérdése, hogy ezen a már megalapításakor ilyen szimbolikus mezőbe kerülö egyetemen a megalakuló magyar, illetve román nyelv és irodalmi szakképzésért felelös tanárok hogyan alakítják ki az új, egyetemi tanári státuszuknak, illetve az általuk művelt tudományszaknak megfelelő szakmai identitást. Milyen szakmai önleírásokat adnak magukról, szaktudomány-, illetve irodalomfogalmuk milyen tartalmakat kap, valamint milyen önlegitimációs stratégiákat applikálnak. ${ }^{2}$

\section{AZ ÚJONNAN MEGNYITOTT KOLOZSVÁRI EGYETEM ÖNÉRTELMEZÉSEI}

Bár a kolozsvári egyetemet a budapesti mintájára szervezik meg, az, hogy például a Bölcsészet- Nyelv- és Történettudományi Karról már az alapításkor leválasztják a Matematikai és Természettudományi Kart, valamint hogy a központtól való földrajzi távolsága miatt valamivel nagyobb autonómiát élvez a budapesti egyetemhez képest, arra enged következtetni, hogy idöben későbbi felállítása okán professzionalizálódottabb intézmény a pestinél. Valójában azonban számos lokális, a kolozsvári adottságokból is következő kompromisszumot kell hoznia Erdély egyetemének, bizonyos esetekben akár a hagyományosan hivatásosodási tendenciákként értelmezett intézménytörténeti mozgások ellenében. Így például, bár a kolozsvári egyetemen a természettudományokat már leválasztották a humán tudományokról, ezeknek a karoknak egyetlen épületen kellett osztozniuk, egymás melletti termekben tartottak órát, s megtörtént, hogy az irodalomórákat zavarták az épület második emeletén ketrecekben tartott, az élettani intézethez tartozó

\footnotetext{
${ }^{2}$ Az egyetemi hivatásosodást vagy professzionalizációt érintő gondolatmeneteim magyar viszonylatban Szivós Erika (Szívós E. 2000), Keller Márkus (Keller M. 2010) és T. Szabó Levente (T. Szabó 2007, T. Szabó 2008) professzioalizáció-fogalmaira támaszkodnak.
} 
állatok. ${ }^{3} \mathrm{Az}$, hogy a Matematikai és Természettudományi Karon oktató Brassai Sámuel szanszkrit nyelv tanithatására vonatkozó kérését vagy a Mahabharátáról tartandó összehasonlitó nyelvészeti és filozófiai előadásait mind Budapest, mind pedig a kolozsvári bölcsészkar nagy örömmel fogadta (KÁL-BTK 1874-5/194), jelezheti számunkra, hogy az egyes tudományterületeket nem határolták mereven a szakmaiság újfajta normái. Ugyanezt láthatjuk a karon belül is, az ösztöndíjra benyújtott pályamunkák elbírálásánál, ugyanis az egyes tudományágaknak csupán egyetlen oktatója volt a karon, így a benyújtott pályamunkákat két szakos tanár hiányában szükségszerüen egy más szakból érkező oktató is elbírálásban részesítette.

Ezek a lokális jellemzők speciális viszonyba hozták az egyetemen oktatott tudományokat. A Kolozsvári Állami Levéltár egyetemi fondjában a bölcsészkar fennmaradt iratai között számos, a termek elosztásának problémáit tárgyaló, a teremhiány orvoslását célzó dokumentum található. ${ }^{4} \mathrm{Az}$ egyetem épületében található faliórák kis számát orvoslandó a második tanévtől egyetemi csengő szabályozza a tanórák menetét, ${ }^{5}$ szimbolikusan leválasztva ezzel az oktatásnak szentelt időt a szabadidőröl, hallható, mindenkire érvényes ritmust kölcsönözve ezzel az egyetemi oktatás menetének - igy lépésről lépésre haladva az első években leszabályozzák a professzionális tudományművelésnek, a szaktudomány átadásának és elsajátításának a kereteit, feltételeit és lehetséges módjait.

„Addig, míg az egyetemi oktatás külön törvény által nem szabályoztatik, a pesti magyar királyi tudomány-egyetemen jelenleg fennálló szabályok ezen egyetemre nézve is érvényesek, a mennyiben jelen törvény mást nem rendel." (XIX. törvénycikk. 1872) A kolozsvári egyetem felállításáról szóló törvénycikk 2. paragrafusának eme rendelkezése egyszerre volt nyüg és érvelési alap a kolozsvári egyetem számára, ugyanis rugalmatlansága lehetetlenné tette, hogy a kolozsvári helyi viszonyokból adódó problémákat kezeljék, ${ }^{6}$ viszont mikor nehezményezik, hogy fizetéseik jóval szerényebbek budapesti kollégáik jövedelménél, azt kérik, hogy az anyagi források tekintetében is hasonló módon járjanak el mindkét intézmény esetében, azaz növeljék meg a kolozsváriak fizetését. ${ }^{7}$ A megalakuló kolozsvári egyetem tehát a budapestivel közös müködési szabályzat ellenére nem követi mindenben a fövárosi struktúrákat, igyekszik minél több területen megörizni önálló döntéshozatali jogát, számos tekintetben nem veti alá magát a pesti egyetemi ügyintézési rendnek. ${ }^{8}$

\footnotetext{
${ }^{3}$ „,Ezen kir. tud. egyetem tkts: bölcsészet kari tanár testületének 236-873/4. kari sz. a. előterjesztése alapján felkéri a tanács a tkts: orvoskari tanár testületet, sziveskedjék az élettani intézet fönöke által intézkedést tétetni, hogy az egyetemi épület első emeletén a 15. és 16. sz. szobák közelében elhelyezett állat ketrec - minthogy azok nyivogásai által a megnevezett tantermekben az elōadások zavarva vannak, s különben is a folyosón levő rosz lég és tisztátalanság jövőre kikerülése ezt kívánatossá teszi - onnan eltávolíttassék. - Amidőn a tanács erre a tkts: kart felkéri, tudatja egyszer s mind, hogy az egyetemi második udvar valamely félre eső helyén az intézeti fônök úr kívánatára mutasson ki alkalmas helyet azon ketrec számára. / A kir. tud. egyetem tanácsának f. évi május 30-án tartott rendes üléséből. - Kolozsvártt 1874 június hó 8-án. Dr. Machik m. k. e. i. rector" (KÁL-BTK 1873-4/244)

${ }^{4}$ Az 1873-4. tanévben pl. a 6, 29, 74, 276-os iktatási számú dokumentumok. (KÁL-BTK)

${ }^{5}$ „Az egyetemi tanácsnak értésére esvén, hogy az óránkénti jeladás hijảnyában egy részt a tanárok nem birnak tamponttal előadásaik tartamára nézve, másrészt, a hallgatók mennek későbben az elōadásokra, hogy a szükségen segitve legyen, a harangjelzést hozta be és egy csengettyũnek az egyetemi fóépûlet elsõ és második emelete közt - a lépcső és hosszú folyosó közötti helyen elhelyezését rendelte el." (KÁL-BTK 1873-4/127) ${ }^{6}$ Például mikor Imre Sándor, a magyar nyelv és irodalom tanszék vezetôje javasolta a magyar nyelv és irodalom felvételét a kolozsvári egyetem mellett mủködõ tanárképezde tantárgyai közé, a vallás és közoktatásügyi miniszter, Trefort Ágoston miniszteri leiratban közölte, hogy nem engedélyezheti, „,miután a törvényhozás a kolozsvári egyetemre nézve a pesti egyetem fennálló szabályzatai szem elött tartását tette kötelességévé". (KÁLBTK 1872-3/100) Amint a pesti egyetemen is felvették a rendes tantárgyak közé, Imre Sándor is elkezdhetett órákat tartani magyar nyelv és irodalomból a kolozsvári tanárképezdében. (KÁL-BTK 1873-4/85)

${ }^{7}$ 1872. december 19-i dokumentum, KÁL-BTK 1872-3/34.

${ }^{8}$ L. pl. az 1873-4-es egyetemi év 77. számú dokumentumát, amelyben az egyetemi hivatalos információáramlás egyetemre szabott kereteit alakítják ki.
} 


\section{A KOLOZSVÁRI EGYETEM ELSŐ OKTATÓINAK ÖNÉRTELMEZÉSEI}

Az egyetem, felállításának pillanatától kezdve, bonyolult professzionalizációs mozgásban lévő intézmény, ami egyáltalán nem jelenti azt, hogy ezt telikus, a kevésbé professzionalizált felől a professzionalizáltabb állapotba való mozgásként kell elképzelnünk - inkább az ideális megoldást kereső, tapogatózó válaszkísérletekként a kor szaktudomány fogalmát és müvelésének lehetséges módjait érintő provokációjára.

Ebben az intézményi keretben értelmezhetjük Imre Sándor és Grigore Silaşi szakmai identitásának alakulását tanszékvezetőségük alatt.

\subsection{AZ EGYETEMI TANÁRI IDENTITÁS MINT GENERÁCIÓS KÉRDÉS}

A Kolozsvári Magyar Királyi Tudományegyetem első 14 évében, 1872 és 1886 között a magyar nyelv és irodalom tanára Imre Sándor, a román nyelv és irodalomé pedig Grigore Sila $\square \mathrm{i}$, mindketten tanszékvezetők (ebben az időben egy tanszéket egy tanár töltött be). Irodalomfogalmuk megértéséhez szaktudósi, egyetemi tanári, nemzeti identitásaik jellemzőit egyaránt vizsgálat tárgyává kell tennünk. E két irodalomtudós ugyanabban a periódusban tanított az egyetemen, távozásuk éve is megegyezik. Egyetemi kinevezést kapva, mindkettőjük arra kényszerült, hogy a frissen kapott társadalmi és szakmai szerepnek megfelelö újfajta szakmai identitást konstruáljon meg a maga számára. Meg kellett felelniük ugyanis egy újfajta, a professziójuk által diktált szakkompetenciának, meg kellett határozniuk új helyüket szakmájuk kompetencia-hierarchiájában (Klinge M. 2004. 127). Az általuk választott professzionális identitás megkonstruálásával összefüggésben alakították ki az általuk - már nem csupán irodalomtudósként, hanem - egyetemi tanszékek vezetőiként képviselt tudományszemléleti rendszert.

Ezzel a problémával nem csupán ők ketten, hanem az egyetem teljes tanári kara szembesült. Az oktatás pragmatikus részének megszervezésén túl mindenik oktatónak egyénileg kellett kidolgoznia önnön tudósi, egyetemi tanári identitását, a hozzá kapcsolódó tudományeszményt és pedagógiai stratégiát. Az egyetemen tanító tanárok tudományterületük professzionalizációjának különböző fázisaiban váltak azok szaktudósaivá, többük még a 19. század eleji literátor-fogalomhoz közelebb álló szaktudós identitással rendelkezett, ám egyetemi kinevezésükkel óhatatlanul integrálódtak a modern szaktudományok rendszerébe, annak keretei között kellett megtalálniuk helyüket, kialakítaniuk szakmai identitásukat. Az a karrier-kép, amelyet többük még a literátori tudóseszmény alapzatán állva alakított ki a maga számára, egyetemi tanárrá válásukkor összeütközésbe került az újfajta értelmiségi elit kanonizálódó pályaképével, valamint ehhez kapcsolódóan a század elejének tudósfogalma csupán kompromisszumokkal volt adaptálható az ủj rendszer követelményeihez. Nevralgikus pontokként folytonos problémát okoztak a régi rendszer azon elemei, amelyek az új tudóseszmény-fogalomba integrálhatatlanoknak bizonyultak. Példa lehet erre a tanárok nagy részének esetében a doktori cím hiánya, amely - egészen megoldásáig - folyamatosan akadályt gördít az egyetemi rendszer olajozott müködése elé. A bölcsészkaron például az első években csupán három tanár rendelkezett doktori címmel, és ráadásul épp ök voltak a legfiatalabbak a tanári kar tagjai közül: dr. Grigore Silaşi, dr. Hóman Ottó és dr. Hugo von Meltzl. Nem meglepő hảt, hogy a többiek is mihamarabb meg szerették volna szerezni doktori címüket. ${ }^{9}$ Ebben a kontextusban a doktori cím annak a szakmai életút-ideálnak a csúcspontja volt, amely a század utolsó negyedében, az idősebb generációhoz tartozó tanárok karrierjének felívelése után alakult ki. Ök nem rendelkeztek ekkor még ezzel a címmel, de kénytelenek voltak lépéseket tenni megszerzése érdekében, ugyanis hiánya miatt folyamatosan háttérbe

\footnotetext{
${ }^{9}$ „Nagyméltóságú Miniszter Úr! / Karunk f. hỏ 7-én tartott rendes gyülésében egyhangúlag kimondta, hogy azon tagjainak, a kik még eddig nem doctorok, (u. m. Felméri Lajos, Fináli Henrik, Imre Sándor, Ladányi Gedeon[,] Szabó Károly[,] Szamosi János és Szász Béla), tiszteletbeli tudor czímet, s oklevelet óhajt adni [...] Kelt

Kolozsv. Decemb. 15. 1873." (KÁL-BTK 1873-4/131)
} 
szorultak doktor kollégáikkal szemben. Ilyen helyzet volt például a külföldön szerzett doktori címek honosítása, amelyet igy csupán a három ifjú tanár volt jogosult elvégezni a kolozsvári egyetem bölcsészkarán. ${ }^{10}$

\subsection{SZAKTUDÓS SZEREP-ÉRTELMEZÉSEK}

Az ezzel a címmel ekkor még nem rendelkező Imre Sándor és dr. Grigore Silaşi tehát nagyon eltérő szaktudós-ideállal a hátuk mögött érkeztek 1872-ben Kolozsvárra, hogy elfoglalják azokat a tanszékeket, amelyekre kinevezték öket. Mindkettejük esetében megállapitható azonban, hogy nemzetfogalmaik tartalma nagyban meghatározta e két tudós irodalomtudományról, nyelvtudományról való gondolkodását, és egyben kijelölt számukra egy általuk roppant fontosként érzékelt szerepet koruk társadalmában.

Ha megfigyeljük az általuk tanított tárgyakat, valamint az ebben az idöben publikált írásaikat, sokatmondó egyezésekre bukkanunk. Nyelv- és irodalomtanárok voltak, érdekes módon azonban mindkettejük munkásságában a nyelvészeti kutatások játsszák a meghatározó szerepet az ilymódon kissé háttérbe szorult irodalomtudomány rovására. Kutatásaik jól láthatóan egyazon irányba tartottak: a nyelvtörténet, valamint a népmüvészet és a nyelvjárások kutatásának fontosságát több írásukban is hangsúlyozták, és munkásságuk meghatározó részét mindketten ennek is szentelték. ${ }^{11}$ Szaktudományos érdeklödésük iránya, mint majd látni fogjuk, nem független attól a szaktudós-szereptől, amely egyetemi tanári kinevezésükkel idnetitás-komponensként beépül önértelmezésükbe.

Tudományszakjuk legitimálását célzó okfejtéseikben a két tanár tudományszemlélete és szaktudósi önértelmezése körvonalazódik számunkra. Mindkét szaktudós véleménye szerint az irodalom- és nyelvtudomány a nemzetük életképességét hivatott bizonyítani. Sila $\square \mathrm{i}$ úgy gondolja, hogy ezen tudományterületek fejlödése a nemzet maturizálódását jelzi, azt, hogy egy nemzet eljutott az öntudatnak azon fokára, hogy képes az önreflexióra. ${ }^{12}$ Imre viszont abból a szempontból látja ezen tudományokat létfontosságúaknak egy nemzet számára, ahonnan a nyelv- és irodalomtudomány feladata felkutatni és terjeszteni az ősi nemzeti nyelv és kultúra sajátosságait, segítve ezzel a nemzetet a helyes út megtalálásában, azaz az irodalomba és nyelvbe került idegen elemek kiküszöbölésében. Azt állítja, hogy a ,nyelv pedig minden nemzetnek legfőbb tulajdona, kincse, és a nemzeti életnek ma már csaknem egyetlenegy külön tényezője” (Imre S. 1897. 69). A nemzet legföbb kincsével foglalkozó, azt védelmező tudomány pedig értelemszerüen a legértékesebb nemzeti tudományként jelenik meg Imre gondolatmeneteiben. ${ }^{13}$ Értelmezésében a tisztán nemzeti nyelvi és irodalmi jelenségek megóvása és megtisztítása a kultúrközi kölcsönzések salakjától biztosíthatja egy nemzet továbbélését. Ilyen szempontból teljesen érthetö, hogy mindketten a nyelvtudományt

\footnotetext{
${ }^{10}$ Fennmaradt Imre Sándornak egy Finály Henrikhez címzett dékáni levele, amelyben arról értesít, hogy Meltzl Hugó távolléte miatt a másik doktori címmel rendelkező kollégát, Silaşit kéri meg a nosztrifikáció elvégzésére. (KẢL-BTK 1873-4/31)

${ }^{11}$ A vizsgált korpusz legfontosabb primér szövegei: Silaşi G. 1874, Silaşi G. 1875, Silaşi G. 1876, Silaşi G. 1879a, Silaşi G. 1879b, Suciu D. 2006, Imre S. 1865, Imre S. 1875, Imre S. 1885, Imre S. 1891, Imre S. 1897 , Imre S. 1900.

${ }^{12}$ „Omulu la inceputulu etatei e mai numai obserbatoriulu celoru ce se petrecu in giurulu seu, imitatoriulu acestoru si trebue se inainte in ani, pana candu se reflecte la interiorulu seu si se'si scia aprofindá individualitatea. Asia si in literatura. / Desvoltarea cunoscintiei nóstre proprie si stim'a de noi suntu cele doue aripe, pre cari se ridica poesi'a poporale. [Élete kezdetén az ember a körülötte zajló dologknak csupán szemlélője, utánzója, és majd élete előhaladtával tud önmagäba nézni és egyéniségét elmélyiteni. Ugyanigy az irodalom is. / Az önmagunkról való tudásunk és öntudatunk kialakulása azokat a szárnyakat képezi, amelyeken a népköltészet felemelkedik.]" (Sila $\square$ i G. 1876. 207)

13 „Legnagyobb mestereinktől, kik a nyelv ẻletére tekintve s a nemzeti érvek szemmel tartásával írtak a nyelvrỏl, azt tanúltam, hogy ennek romlása ellen küzdenünk kell, csak úgy, mint az erkölcsök romlása ellen. Ezért tanúljuk a múltat, a nemzet állami és magánélete s nyelve történetét, hogy ezt tudjuk és akarjuk it tenni." (Imre S. 1897. 70)
} 
részesítik előnyben az irodalomtudományi vizsgálódással szemben. Azonban míg Sila $\square$ i ezt azért teszi, mert úgy gondolja, hogy a filológia a tudományok királynöje, mert a nyelvvel foglalkozik, vagyis azzal, ami az embert megkülönbözteti az állattól, ${ }^{4}$ addig Imre úgy látja, hogy a nyelvtörténet következtetéseinek applikálása korának nyelvére a nemzet erkölcsi felemelkedését jelentené, ugyanis az említett keveredés, a nemzet tisztaságának elveszése az ő gondolkodói rendszerében összekapcsolódik egy apokaliptikus, visszafordíthatatlan erkölcsi romlás képével, amelyet legföként a virágzó és szakértelemmel müvelt nyelvtudomány gátolhat meg. ${ }^{15}$

A nyelvtudomány egy partikuláris kérdése, a dialektusokkal kapcsolatos téziseik esetében is ugyanezen logika szerint térnek el egymástól, bár első látásra csupán az tủnik fel, hogy mindketten meglehetősen nagy fontosságot tulajdonítanak a nemzeti nyelv dialektusai vizsgálatának. Imre a vegyes etnikumú vidékek dialektusait a tiszta nyelv elkorcsosult változataiként, az idegen népektől érkezett hatások eredményeként értelmezi, ${ }^{16}$ és szorgalmazza az egy, közös, tiszta nyelv kinyerését a népköltészet alkotásainak nyelvébỏl. ${ }^{17}$ Sila $\square$ i úgy véli, hogy a nemzeti nyelv különböző dialektusainak vizsgálatával és összevetésével a nemzeti múlt rejtélyeit fejthetjük meg, hiszen sok esetben egyetlen hangtani különbség okainak felderítése az idők során különböző területeken szétszóródó nemzet különböző életkörülményeinek, viszonyainak történeti feltárásához vezethet. ${ }^{18}$ Mindketten az egy közös eredeti nyelv kinyerésén fáradoznak, ám amíg Imre az öseredeti magyar nyelv sajátosságait keresi, elvetve annak lehetöségét, hogy a variánsok önmagukban is értékesek lehetnek, a román nyelv- és irodalomtudományt Romániához képest külföldön képviselö

\footnotetext{
${ }^{14}$, ,F]ilologi'a prein scienti'a moderna este prochiamata de culmea si regin'a toturaru scientiloru, intocmai precumu omulu (cu a carui limba se ocupa ea, cá cu distinctiunea lui principale de càtra animalele necuventatórie, e misteriulu si totodata chiaea scientiloru naturali, e culmea si corón'a creatiunei). [A modern tudományok közül a filológiát az összes tudomány felett állónak, a tudományok királynőjẻnek tekintik, éppen úgy, ahogyan az embert is (akinek a nyelvével mint a beszélni nem tudó állatoktól való legfontosabb megkülönböztetőjével foglalkozik, amely a természettudományok rejtélye és egyúttal kulcsa is, a teremtés csúcspontja és koronája)]" (Sila $\mathrm{i}$ G. 1874. 89)

15 „Mert a sok nyelvű népnek [...] sok esze, azaz sokfelé irányuló eszejárása van; a sok ész sok küzdéssel,
} surlódással élvén, kiformálódik a legképtelenebb nézetek tetszetôs vitatására is. De utóljára megzavarodás áll be a felöl, mi a jobb, mi az igaz és jogos. Az érdek, az önérdek nagyon hatalmas sophista. Ebből az következnék, hogy a hazafiak összedugott kézzel nézzék és szó nélkül hagyják nemzetiségök elegyedését, hagyományaiknak emlékezetböl kitörlését, történelmök meggyalázását, röviden szólva nemzetök, nagyobb családjok lassú kihalását. Ezt kívánná a világpolgári bölcseség [...] Ilyen törekvést örültség volna elfogadni vagy elméletben helyeselni addig, míg látjuk, hogy a legnagyobb nemzetek nemes fiai a nemzetiségért küzdenek, tehát úgynevezett nationalisták." (Imre S. 1897.67-68)

${ }_{16}^{16}$ „Az elegyedés lehet önkéntes, kivált a népnél, a épéletben, a nemzet hazájának határaiban, vagy idegenekkel vegyưlt tájékain. Így van folyamatban a mi népünk elegyülése a nyelvre nézve is egyfelöl a némettel, másfelöl a tóttal és délszlávval s a ruménnel. [...] Az erdélyi tájakon a székely és általán magyar beszéd nem kevés oláh szólással és szóval van vegyítve [...] A nyelv ily vegyülése ellenállhatatlan; bizonyos, hogy néha beljebb is terjed a határoktól, a müveltek nyelvében is elhatalmazik. Ily körülmény okozza, hogy a nép nyelvérzéke kisebbnagyobb mértékben gyengül, végre a népet $s$ még inkább a müveltebbeket a nyelv rendszere iránt lassanként érzéketlenebbekké teszik a korcs szólások." (Imre S. 1897. 80-81)

17 „A nép szava Isten szava. [...] Természetes hangok az őskorból, a paradicsomból vagy a sivatagból. [...] A nevelés és iskolázás pedig e szellem megóvására és megerősítésére tartozik törekedni: a népben levő őserőt, a társadalomban a népiest (Volksthümlich) megtartani és tenyészteni." (Imre S. 1885. 279-280)

${ }^{18}$ „Estmodu limb'a ne este sî aici, cá sî aiure demulteori, unu caleusu sî manuducatoriu dein celi mai siguri la constatarea fapteloru istorice. [...] Chiaru de aceea e necessaria sî pentru noi romanii culegerea sî a celoru mai neinsemnate amenuntîmi, ce ne presenta limb'a in dialectele sale, provincialismii, idiotismii sei, in proverbîe scl. Demulteori unu cuventielu ti-deschide prospectu sî lumea scientieloru. [Ilymódon a nyelv itt is, ahogyan sok esetben másutt is, a legbiztosabb kalauzok és útmutatók egyike a történelmi tények megállapításában. [...] Épp ezért számunkra, románok számára is szükséges a legjelentéktelenebb apróságok felgyüjtése is, amelyek nyelvünket dialektusaiban, provincializmusaiban, idiomatizmusaiban, közmondásaiban és hasonlókban jelenítik meg. Sok esetben már egy szócska is betekintést nyújthat a tudományok világába.]" (Sila $\square$ i G. 1874. 175) 
Silaşi saját kutatási területei partikularitásának antropológiai hasznosithatóságára hívja fel a figyelmet.

Hasonló érvkészlettel tér el a két oktatónak a dalhoz, a lírához való viszonya is. Mindketten komoly tanulmányokat szenteltek a népdal és népköltészet vizsgálatának, és ez talán az egyetlen kérdés, amelyben valóban közös nevezőn vannak: azért tekintik a nemzeti irodalom legfontosabb müfajának a népdalt, mert a tiszta ösi nyelv, ezáltal pedig a torzítatlan, hamisítatlan nemzetszellem megnyilvánulását látják benne. (Sila $\square$ i G. 1876. - Imre S. 1900)

\section{KÖVETKEZTETÉSEK}

Láthatjuk, e két tudós irodalom- és nyelvszemléletẻhez nemzeti és szaktudósi identitásaik vizsgálata szolgáltathatja a kulcsot, és megmutathat számunkra olyan összefüggéseket, amelyek nélküle értelmezhetetlenek maradnának. Az általuk múvelt szaktudomány egyik legfontosabb elemeként a nemzeti identitás imperatívuszát emelhetjük ki. Teljes szaktudományos érvrendszerüket, az általuk alkalmazott módszertant, tudósi identitásuk összetevőit mind-mind nemzetfelfogásuk felöl érvelve építették fel s nemzeti identitásuknak rendelték alá. A két oktató teoretikusan kifejtett nézetei azonban a gyakorlatban több esetben csorbát szenvedtek épp szaktudósi identitásuk többarcúsága miatt. Imre Sándor elméletben állította, hogy az idegen nyelvek tanulása káros a nemzeti nyelvérzére, ezért korának ezt a divatját kerülendőnek tartotta a nemzeti nyelv megóvása érdekében, ${ }^{19}$ ugyanakkor a Bölcsészettudományi Kar dékánjaként ő maga fogalmazta meg a kolozsvári tanárképezdének a vallás és közoktatásügyi miniszterhez intézett kérését, melyben Ladányi Gedeonnal egyetértésben kéri, hogy vegyék fel a képezdei tárgyak közé ,az egyik legfontosabb középtanodai kötelezett tantárgy"-at, a német nyelvészet- és irodalmat. (KÁL-BTK 18734/164) Láthatóan itt a tanszékvezetői egyetemi tanári és a nyelv- és irodalomtörténészi identitás került összeütközésbe, vagy inkább váltotta fel egymást a helyzetnek megfelelö identitás elötérbe kerülésével. Silaşi esetében a különböző társadalmi és szakmai szerepeinek megfelelő identitásai inkább kívülről, a nemzetközösségének egy ortodox felekezetủ csoportja felöl mutatkoztak problematikusaknak: a román tanszék vezetőjévé való kinevezésekor számos üdvözlö megnyilvánulás mellett a román sajtóban olyan vélemények is megfogalmazódtak, amelyek szerint Silaşi azért nem megfelelő az általa elnyert állás betöltésére, mert görög katolikus vallása miatt a románságnak csupán egy kis hányadát tudja képviselni nézeteiben, világlátásában. ([n. n.] 1872) Ugyanakkor valójában szakmai identitástudatának azon imperatívusza, hogy a román nemzet történetét számos tudományág felöl megvizsgálja (nyelvtörténeti és irodalomtörténeti vizsgálódásai mellett lásd néprajzi, történelmi kutatásait) épp abban a hivatástudatban gyökerezett, amely román nyelv és irodalomtanárként a nemzeti értékek védelmét írta elő számára.

Dolgozatomban a Kolozsvári Magyar Királyi Tudományegyetem magyar és román nyelv és irodalom tanszékének a példáján keresztül annak értelmezésére tettem kísérletet, hogy a professzionalizáció-történet egy bizonyos pillanatában felállított kolozsvári egyetem szerveződése nem a fejlődéstörténeti logikának megfelelöen alakult, történetének eme részét nem írhatjuk le egy kevésbé professzionális állapottól egy egyre professzionalizáltabb, specializáltabb állapot felé haladásként, hanem a professzionalizáció-történet korábbi fázisainak struktúráiból számos elemet örökölve tulajdonképpen a helyi speciális viszonyoknak és Budapest elvárásainak, határozatainak is megfelelve alakította ki adminisztratív kereteit, és határozta meg tudományszemléleti premisszáit.

\footnotetext{
19 ,nincsen a mi időnknek, a nevelés körében egy-egy ártalmasabb nyavalyája, mint a sok nyelvet tanúlás, - a szegényebb, kisebb népek nyomorúsága. Ez rontja meg alapjában a nyelvérzést és szellemi természetes kifejlést és megerősödést, - tehát azt az alapot, a mely a nemzeti életnek föntartója. [...] A hazait mellőzik amazok miatt; tehát hontalanokká lesznek [...] Korcsokká lesznek; szellemileg és erkölcsikép hazátlanokká." (Imre S. 1897.
} 151) 


\section{Köszönetnyilvánitás}

A dolgozat megírásához szükséges anyagi támogatást a Humáneröforrás-fejlesztési Operativ Program 2007-2013. és az Európai Szociális Alap biztositotta a POSDRU/89/1.5/S/60189 projekt keretébōl: „Posztdoktori kutatási programok egy tartósan fejlödő tudásközpontú társadalomért”.

\section{FELHASZNÁLT IRODALOM}

[n. n.] (1872): Óre ce se fia? [Vajon mi legyen?], Federațiunea 109-709. sz. 435-436.

Imre S. (1865): A magyar irodalom és nyelv rövid története, Debrecen;

Imre S. (1875): Nemzetiség és nevelés, Budapesti Szemle, 17. sz., 40-117;

Imre S. (1885): Népköltés, népdal (gondolattöredékek), Erdélyi Múzeum;

Imre S. (1891): A magyar nyelv és nyelvtudomány rövid története, Bp.

Imre S. (1897): A nyelv romlása = I. S., Irodalmi tanulmányok, I-II. 61-153.

Imre S. (1900): A népköltészetrōl és népdalról, Budapest, Franklin.

KÁL-BTK: Kolozsvári Állami Levéltár, 315. fond, a Bölcsészet- Nyelv- és Történettudományi Kar iratai

Klinge M. (2004): Teachers = A History of the University in Europe, III., Universities in the Nineteenth and Early Twentieth Centuries, Walter RüEGG (szerk.), Cambridge, Cambridge University Press, 123-161.

Silasi G. (1874): Studiu asupra dialectului macedo-romanu paralelu cu celu daco-romanu [Tanulmány a macedo-román és a dáko-román nyelvjárás párhuzamos vizsgálatának tárgyában], Transilvania, 8-15. sz.;

Silasi G. (1875): A maczedoniai román nyelvjárás, Erdélyi Múzeum, 1875/9. sz., 1876/2-3. sz:;

Silasi G. (1876): Romanulu in poesia sa poporale [A román alakja a román népköltészetben], Transilvania, 18-23. sz.;

Silasi G. (1879a): Apologie [Apológia], Kolozsvár, 1879;

Silasi G. (1879b): Renascerea limbei romanesci in vorbire sî scriere [Az írott és beszélt román nyelv újjászületése], Kolozsvár, Editiunea „Amicului familiei”;

Suciu D. (2006): Grigore Silaşi. Scrisorile lui Grigore Sila $\square$ i către George Bari $\square$ iu [Grigore Sila $\square$ inak George Bari $\square$ iuhoz írt levelei], George Barițiu Történeti Intézet Évkönyve, tom. XLV, Kolozsvár, 261-294;

Szivós E. (2000): Kartársak és harcostársak. Vázlat a professzionalizáció magyarországi történetéhez = Bódy Zsombor - Mátay Mária - Tóth Árpád (szerk.), A mesterség iskolája. Tanulmányok Bácskay Vera 70. születésnapjára, Osiris, Bp., 33-59.

T. Szabó L. (2007): Milyen nyelven beszél az irodalom tudománya? Szakszerüsödés és a professzionalizáció nyelvi következményei a 19. század közepén= Filo-logikák. Fiatal kutatók tanulmányai az irodalomtudomány, a nyelvészet és a filozófia köréböl, T. Szabó Levente Zabán Márta (szerk.), Kriterion, Kolozsvár, 491-507.

T. Szabó L. (2008): Az írói nyugdij és írói munkanélkülis ég feltalálása és a modern irodalmár hivatás kimunkálása, Irodalomtörténet 2. sz., 347-376.

XIX. törvénycikk (1872): Fôrendiházi Irományok, I, 1872. 246. 